\title{
Stature Estimation from Radiographic Measurements in Adult Anatolian Population
}

\author{
Estimación de la Estatura a Partir de Mediciones \\ Radiográficas en una Población Adulta de Anatolia
}

Ahmet Kürsad Açıkgöz'; Ahmet Cem Erkman²; Figen Binokay³; Pınar Göker ${ }^{1}$ \& M. Gülhal Bozkir ${ }^{1}$

\begin{abstract}
AÇıKGÖZ, A. K.; ERKMAN, A. C.; BINOKAY, F.; GÖKER, P. \& BOZKIR, M. G. Stature estimation from radiographic measurements in adult Anatolian population. Int. J. Morphol., 39(3):809-815, 2021.

SUMMARY: The purpose of the present study was to create a regression equation for measuring stature using measurements obtained from the long bone radiographs of adult individuals in Anatolian population. In this study, the maximum length measurements of the six long bones in the upper and lower limbs of 167 healthy individuals were determined from radiographic images. Single and multiple regression equations were created to predict the stature of the individuals from the maximum bone stature. From these equations, the standard error of estimate was determined in the range of $1.68-4.09 \mathrm{~cm}$. As a result of this study, the obtained regression equations resulted in highly reliable and successful results in terms of predicting stature. These equations will provide convenient and predictive accuracy in the estimation of stature from skeletal remains obtained from societies that lived and living in Anatolia. Besides, we anticipate that it will guide researchers working in the fields of Forensic Anthropology, Forensic Medicine and Anatomy.
\end{abstract}

KEY WORDS: Radiographic measurements; Stature estimation; Regression equation; Length of the long bones.

INTRODUCTION

Stature is one of four major parameters, along with age, sex and race, that is very important in identifying individuals in forensic anthropology, forensics, and crime scene investigation. It also provides information about many characteristics of a population, including nutrition, health, and genetics (Krishan \& Sharma, 2007).

Stature constitutes very important data, especially for human evolutionary studies. Estimating stature from skeletal remains is part of the process of restructuring the life of an individual and it clearly affects body mass (Carretero et al., 2012). Stature estimation is an indispensable part of the identification process from skeletal remains or body parts, and forensic medicine and anthropological studies in this field (Petrovecki et al., 2007).

Anthropometric investigations have shown that the rates between stature and long bone sizes are constant during the growth period, but vary depending on stature and ancestry. Moreover, studies have shown that in cases where parts of the body or bones were available, these parts may have been sufficient to estimate the stature (Ozaslan et al., 2003; Petrovecki et al.).

Karl Pearson, who was a mathematician, created regression equations for stature estimation in 1899 , which were used effectively in identification in many studies, and resulted in significant progress in studies in this field (Pearson, 1898; Radoinova et al., 2002). However, commonly used equations (Pearson; Trotter \& Gleser, 1952) may not provide accurate results for the stature estimation of individuals from different populations, which can lead to serious inaccuracies, especially in forensic medicine and forensic anthropology. For this reason, the most accurate result in stature estimation can be achieved by regression equations of the population on which it is based (Radoinova et al.).

The aim of the this study was to create a regression equation for measuring stature using measurements obtained from the long bone radiographs of adult individuals in Anatolian population.

\footnotetext{
${ }^{1}$ Department of Anatomy, Faculty of Medicine, Çukurova University, Adana, Turkey.

${ }^{2}$ Department of Anthropology, Faculty of Science and Literature, Ahi Evran University, Kırsehir, Turkey.

${ }^{3}$ Department of Radiology, Faculty of Medicine, Çukurova University, Adana, Turkey.
} 


\section{MATERIAL AND METHOD}

In the present study, a total of 167 people (97 male, 70 female) between the ages of 18-65 with no orthopedic and surgical medical history or pathologies admitting to Çukurova University, Faculty of Medicine, Radiology Department between 2016 and 2019 were included in our study. The study was approved by the Ethics Committee and related departments of the Çukurova University Faculty of Medicine. In addition to the demographic data of the participants, the maximum length measurements of the long bones of 88 people ( 40 female, 48 male) in lower and upper limbs (i.e., humerus, ulna, radius, femur, tibia, and fibula); and the maximum length measurements of the long bones of 79 people (30 female, 49 male) in only lower limb (i.e., femur, tibia and fibula) were taken from their radiographic images.

The Silhouette VR X-ray machine (GE Medical Systems LLC, WI, USA) was used to obtain the images of the patients who were admitted to the radiology department, and the patient collimator distance was set as $120 \mathrm{~cm}$ during imaging. In terms of the reliability of the study, radiological measurements were measured twice by the same researcher and no statistically significant difference was found $(p>0.05)$. Informed consent was given by the patients admitted to the hospital, and their stature was measured by one technician using a stadiometer. Radiological images were obtained from the hospital database. Maximum bone length measurements were performed using Enlil PACS system software (Eskisehir, Turkey) on the radiographic images. Measurements taken from long bones:

- Maximum humerus length (MHL): The length between the highest point of head of humerus and the lowest point of the capitulum of humerus (Fig. 1).

- Maximum ulna length (MUL): The length between the highest point of the olecranon and the lowest point of the ulnar styloid process.

- Maximum radius length (MRL): The length between the highest point of the head of radius and the lowest point of the radial styloid process.

- Maximum femur length (MFeL): The length between the highest point of head of femur and the lowest point of the medial condyle of femur (Fig. 2).

- Maximum tibia length (MTL): The maximum length between the highest and the lowest points of the upper part of the tibia.

- Maximum fibula length (MFiL): The distance between the apex head of fibula and the lowest point of the lateral malleolus.

Statistical analysis of the data that were obtained in the present study was performed using SPSS v.20.0 software (IBM Corp., Armonk, NY, USA). The suitability of the quantitative data for normal distribution was determined using the Kolmogorov Smirnov test. The descriptive analysis was performed to obtain mean, standard deviation and range (minimum and maximum) of the measurements. The paired samples ttest was used for the right-left comparison of the data that showed normal distribution in both sexes. The relation between stature and maximum lengths of the upper and lower limb bones was determined using the Pearson correlation test. The dimensions of maximum lengths of the

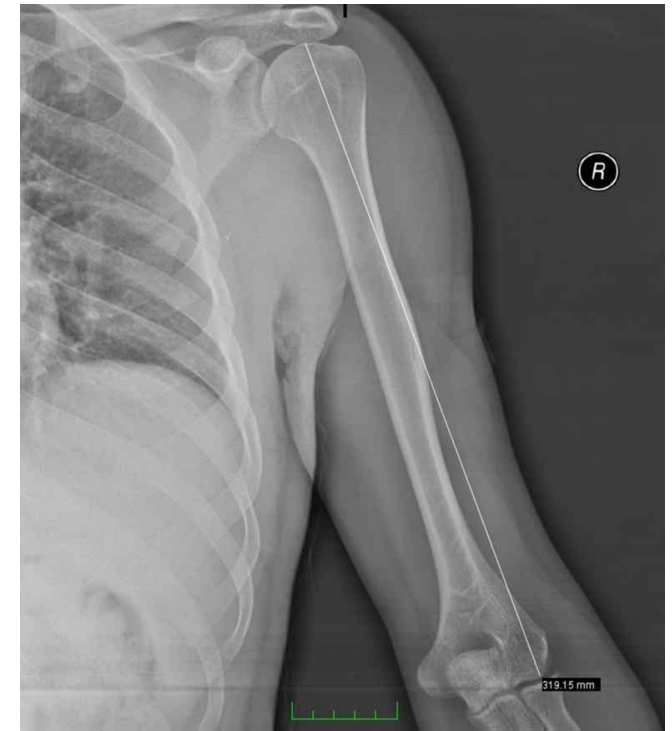

Fig. 1. Maximum humerus length.

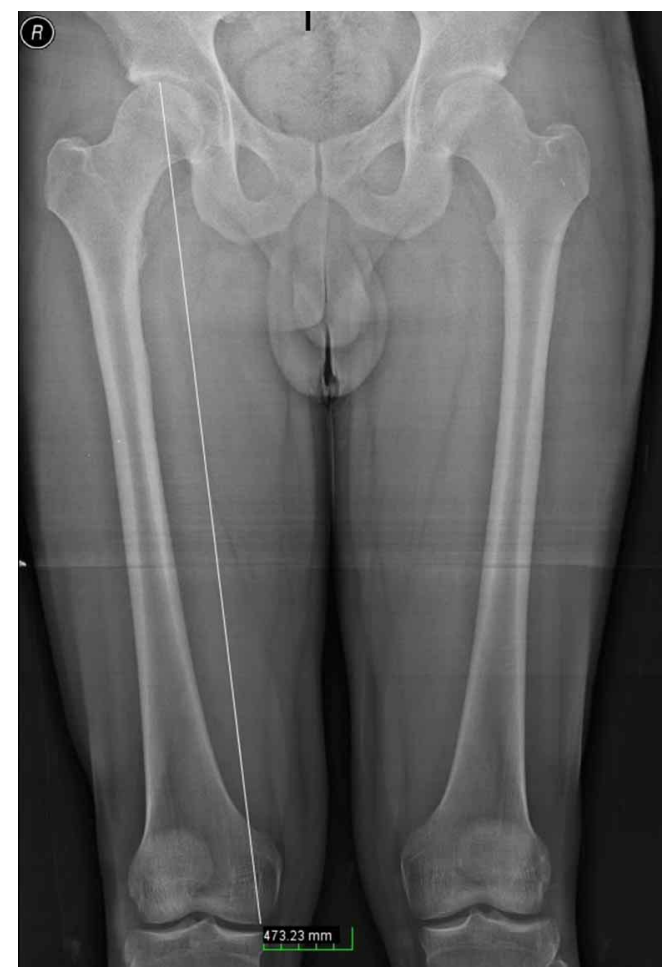

Fig. 2. Maximum femur length.

upper and lower limb bones were used for obtaining a single regression, and the determination coefficient of a regression estimation equation (R2) and standard error of estimate (SEE) were calculated. In addition, a multiple regression equation was acquired by a stepwise method through combining different variables. Statistical significance was accepted as $\mathrm{P} \leq 0.05$. 


\section{RESULTS}

The ages, heights, and maximum lengths of the upper and lower limb bones, which were collected from radiological images, of 167 individuals (70 females, 97 males) are shown in Table I.

The statistical difference between the maximum length measurements of the bones on the right and left sides of the individuals is shown in Table II. A statistical difference in the maximum length of all of the lower and upper limbs of the males was observed $(\mathrm{P}<0.05)$.
The correlation between the maximum length measurements of the bilateral upper and lower limbs bones and the stature was examined (Table III). The highest correlated measurement with stature was determined in the females $(r=0.919)$ and in the males $(r=0.910)$ as the right side maximum humerus length.

Single regression equations were created from the maximum length measurements and standard error of estimate values individuals were shown in (Table IV). All

Table I. Descriptive statistics ( $\mathrm{cm}$ ) of the adult individuals.

\begin{tabular}{|c|c|c|c|c|c|c|c|c|c|c|}
\hline \multirow{2}{*}{ Measurements } & \multicolumn{5}{|c|}{ Females } & \multicolumn{5}{|c|}{ Males } \\
\hline & $\mathrm{N}$ & Min & Max & Mean & SD & $\mathrm{N}$ & Min & Max & Mean & SD \\
\hline Age (years) & 70 & 18 & 65 & 43.03 & 12.62 & 97 & 18 & 61 & 35.01 & 11.40 \\
\hline Stature $(\mathrm{cm})$ & 70 & 150.0 & 183.0 & 161.41 & 6.57 & 97 & 163.0 & 186.0 & 173.54 & 5.26 \\
\hline RightMHL (cm) & 40 & 28.46 & 34.40 & 31.05 & 1.59 & 48 & 30.87 & 40 & 34.06 & 1.88 \\
\hline Left MHL (cm) & 40 & 28.10 & 33.98 & 30.83 & 1.60 & 48 & 30.74 & 39.54 & 33.89 & 1.89 \\
\hline Right MUL (cm) & 40 & 22.48 & 26.87 & 24.64 & 1.07 & 48 & 24.18 & 30 & 26.99 & 1.32 \\
\hline Left MUL (cm) & 40 & 22.22 & 26.61 & 24.43 & 1.08 & 48 & 24.25 & 29.68 & 26.89 & 1.31 \\
\hline Right MRL (cm) & 40 & 20.90 & 25.81 & 22.71 & 1.21 & 48 & 23 & 27.31 & 25.06 & 1.24 \\
\hline Left MRL (cm) & 40 & 20.87 & 25.19 & 22.54 & 1.13 & 48 & 22.49 & 27.10 & 24.95 & 1.23 \\
\hline Right MFeL (cm) & 70 & 38.46 & 50.67 & 43.73 & 2.47 & 97 & 44.29 & 54.40 & 47.89 & 1.89 \\
\hline Left MFeL (cm) & 70 & 38.83 & 50.32 & 43.82 & 2.35 & 97 & 44.31 & 55.30 & 48.01 & 1.95 \\
\hline RightMTL (cm) & 70 & 31.75 & 42.26 & 35.62 & 2.17 & 97 & 36.38 & 45.43 & 39.43 & 1.85 \\
\hline Left MTL $(\mathrm{cm})$ & 70 & 31.84 & 42.11 & 35.74 & 2.12 & 97 & 36.24 & 45.19 & 39.54 & 1.88 \\
\hline Right MFiL (cm) & 70 & 30.70 & 41.30 & 34.70 & 2.18 & 97 & 34.70 & 44.23 & 38.27 & 1.78 \\
\hline Left MFiL (cm) & 70 & 31.11 & 40.70 & 34.73 & 2.08 & 97 & 35.10 & 44.17 & 38.37 & 1.82 \\
\hline
\end{tabular}

Table II. Bilateral differences in the maximum length measurements of the adult individuals.

\begin{tabular}{|c|c|c|c|c|c|c|c|c|}
\hline \multirow[b]{2}{*}{ Measurements } & \multicolumn{4}{|c|}{ Males } & \multicolumn{3}{|c|}{ Females } & \multirow[b]{2}{*}{ P-value } \\
\hline & $\begin{array}{l}\text { Mean difference } \\
\text { (right-left) }\end{array}$ & SD & T-value & P-value & $\begin{array}{c}\text { Mean difference } \\
\text { (right-left) }\end{array}$ & $\mathrm{SD}$ & $\mathrm{T}$-value & \\
\hline MHL & 0.174 & 0.256 & 4.716 & $<0.001$ & 0.217 & 0.233 & 5.904 & $<0.001$ \\
\hline MUL & 0.099 & 0.282 & 2.439 & 0.019 & 0.201 & 0.194 & 6.563 & $<0.001$ \\
\hline MRL & 0.110 & 0.248 & 3.082 & 0.003 & 0.170 & 0.196 & 5.494 & $<0.001$ \\
\hline MFeL & -0.119 & 0.467 & -2.514 & 0.014 & -0.087 & 0.429 & -1.708 & 0.092 \\
\hline MTL & -0.109 & 0.381 & -2.822 & 0.006 & -0.115 & 0.363 & -2.653 & 0.010 \\
\hline MFiL & -0.099 & 0.355 & -2.747 & 0.007 & -0.031 & 0.398 & -0.663 & 0.509 \\
\hline
\end{tabular}

\begin{tabular}{lcccc}
\hline \multirow{2}{*}{ Measurements } & \multicolumn{3}{c}{ Males } & \multicolumn{2}{c}{ Females } \\
\cline { 2 - 5 } & Right & Left & Right & Left \\
\hline MHL & $0.910^{* *}$ & $0.894^{* *}$ & $0.919^{* *}$ & $0.896^{*}$ \\
MUL & $0.833^{* *}$ & $0.823^{* *}$ & $0.875^{* *}$ & $0.861^{*}$ \\
MRL & $0.808^{* *}$ & $0.753^{* *}$ & $0.851^{* *}$ & $0.853^{*}$ \\
MFeL & $0.737^{* *}$ & $0.777^{* *}$ & $0.841^{* *}$ & $0.855^{*}$ \\
MTL & $0.736^{* *}$ & $0.729^{* *}$ & $0.811^{* *}$ & $0.809^{*}$ \\
MFiL & $0.707^{* *}$ & $0.714^{* *}$ & $0.806^{* *}$ & $0.797^{*}$ \\
\hline
\end{tabular}

Table III. Correlation between the stature and limbs measurements.

**Significant at 0.01 (twotailed). 
of these regression equations were statistically significant $(\mathrm{P}<0.05)$.

Multiple regression equations were created from the long bone measurements of the upper and lower limbs of the females, males, and both genders together (Table V). All of the regression equations created were statistically significant $(\mathrm{P}<0.05)$. The standard error estimate values for the multiple regression equations ranged between 1.68 and $2.24 \mathrm{~cm}$.

\section{DISCUSSION}

Stature estimation from various skeletal sections has been an important topic for forensics, anthropologists, and anatomists for more than 100 years. Different mathematical techniques have been developed to create a stature estimation from skeletal remains (Ozaslan et al.). Stature estimation is based on two main foundations. The mathematical method, which uses regression equations or multiplication factors and requires the full bone, and the anatomical method, which requires the presence of a complete skeleton. However, the anatomical method is almost impossible to apply to remains from wars, mass disasters, accidents, and murders where the body parts were dismembered. In such cases, the mathematical method is applied. Body ratios of different populations vary not only with ethnicity, but also with geographical conditions, nutrition, physical activity, and environmental factors. For these reasons, the use of regression equations, created for different societies, might not produce the right results on a specific population. For this reason, the regression equations
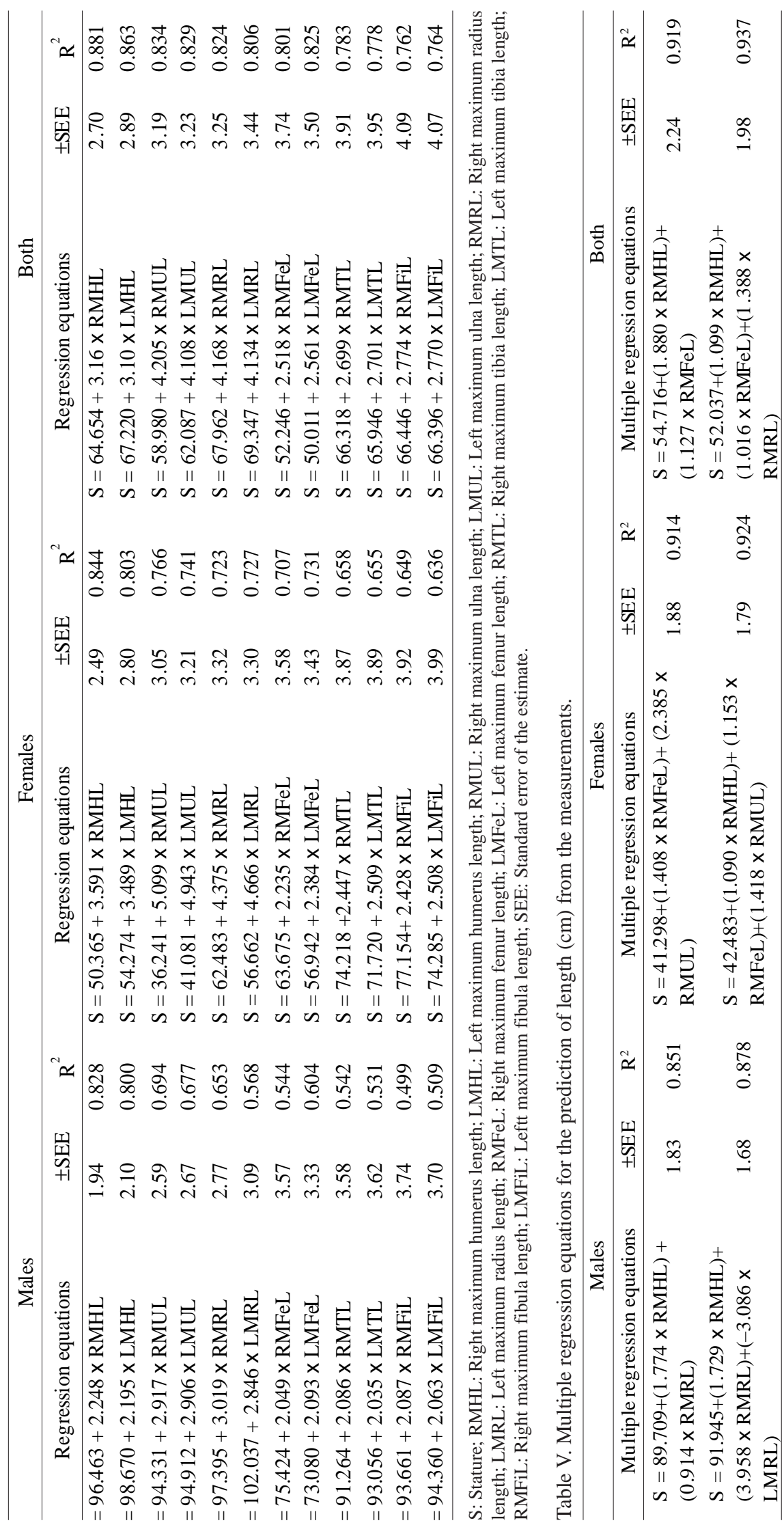
for use in stature estimation must be designed with the understanding that the most accurate biological and genetic profiles are created using standards that are specific to a target population. Since there are different biological relation degrees between extremities and stature, bones of the lower and upper limbs have been used in many studies to estimate stature (Ahmed, 2013a). The materials of these studies were skeletal collections, cadavers, anthropological measurements of living individuals, and radiological images of the individuals. It is our belief that it is not objective to evaluate these different measurement materials and methods within the same group. For this reason, evaluations must be made using different materials and methods.

The studies that have been conducted to predict stature in living individuals were mostly studied using the regression equation created as a result of statistical analysis of the direct anthropometric measurements of individuals. Based on the measurements of various parts of the body in various populations, the stature regression equation of that specific population was created. Many researchers have performed investigations using this measurement method in the Middle East, Africa, Europe, Asian communities, and Turkey. When the studies carried out in Turkey were first considered, single and multiple regression equations were created for stature estimation from the resulting length, height, and width measurements from various body parts of students from different areas, hospital staff, military staff, and orthopedically healthy patients, and individuals of various age groups and lifestyles. In these equations, the standard error of estimate was between 2.69 and $10 \mathrm{~cm}$. The best estimate was based on the leg and thigh lengths, and size of the tibia in the single regression equations, and large body parts like the tibia and ulna in the multiple equations (Ozaslan et al.; Duyar et al., 2006; Zeybek et al., 2008).

The standard error of estimate was reported as ranging from 2.75 to $8.66 \mathrm{~cm}$ in the equations created in studies conducted on communities of the Africa (Sudan, and Ghana). The best prediction measurements were obtained from the length of the foot, ulna, and tibia in the equations of these studies, and the estimates indicated that lower extremity measurements could yield better results than those of the upper extremity (Ahmed, 2013a,b; Abledu et al., 2016;). In the equations for Indian individuals, the standard error of estimate ranged between 2.06 and $6.19 \mathrm{~cm}$, and the length of the foot, and hand in both sexes were the measurements that provided the best estimations (Krishan \& Sharma; Sen et al., 2014). Studies conducted in China and South Korea showed that standard estimated errors were in the range of 2.96 and $6.47 \mathrm{~cm}$ in the regression equations, and the best estimate was obtained using the hand breadth and length measurements (Tang et al., 2012; Jee \& Yun, 2015). In the regression equations created for individuals belonging to Slovakia populations, the standard error of estimate was reported as ranging between 4.41 and $6.11 \mathrm{~cm}$, and the best estimate was obtained using the foot length measurement equation (Uhrová et al., 2015).

Although, forensics and anatomists have benefited from the use of corpses and cadavers in some studies in the literature, they have not been used frequently due to reasons like the inaccessibility and insufficient number of materials for height and stature, respectively. Specifically, in cases where the full body parts of the victim are unavailable or only certain limbs, such as the hands, fingers, arms, and legs are present, the regression equations that were created previously and were specific to the community will contribute to the acquisition of information about the victim profile. It was observed in Turkey that the radius length provided the best predictive relation, especially in single regression equations that were created in cadaver stature prediction studies. In addition, the measurement of fresh cadavers may have higher sensitivity when compared to dry bone remains (Celbis \& Agritmis, 2006). In studies conducted on Asian societies (Malaysia, and Korea), single and multiple regression equations were created for stature predictions, and the standard error of estimate in the single regression equations was between 2.91 and $8.53 \mathrm{~cm}$, while that in the multiple regression equations was between 3.73 and $5.27 \mathrm{~cm}$. Moreover, the lower leg and thigh lengths, and maximum femur and tibia lengths were the measurements used to obtain the best estimations (Nor et al., 2013; Lee et al., 2014). Single and multiple regression equations were developed for stature estimation from the bones of the lower and upper limbs in studies conducted on cadavers of individuals in European and Balkan countries (Portugal, Croatia, and Bulgaria). In these equations, the standard error of estimate was between 2 and $8.44 \mathrm{~cm}$, and the most successful estimate was in the stature measurements based on the long bones (De Mendonça, 2000; Radoinova et al.; Petrovecki et al.).

The frequency of radiological studies has increased over recent years due to present day opportunities in stature estimation. The main preferences for performing these studies includes advantages such as data not deteriorating over time, the lack of damage to human skeletons, application being possible to living individuals, the lack of skeletal preparation, and efficient usage of time. Single and multiple regression equations were created using body mass indices and body weight data via hand measurements taken from individuals in studies conducted in Turkey using radiological images. In these equations, the standard error of estimate ranged between 0.87 and $5.96 \mathrm{~cm}$ (Karaman et al., 2008). The standard error of estimate in the equations created in 
studies on individuals in European and Balkan countries was observed in the range of 2 and $5.21 \mathrm{~cm}$ (Italy, Switzerland, and Croatia), and the highest estimate was obtained from the long bone and first metatarsal measurements (Petrovecki et al.; Giurazza et al., 2012; Zech et al., 2016). When Asian societies were considered (Japan and Malaysia), the single and multiple regression equations created from radiological images showed a standard error of estimate between 2.16 and $15.99 \mathrm{~cm}$, and the best estimation relation was made based on the femur, humerus, radius, ulna, tibia, and fibula lengths (Hasegawa et al., 2009; Ismail et al., 2018). In most of the studies, it was observed that more successful predictions could be obtained from multiple regression equations than from single equations (Ozaslan et al.; Duyar et al.; Karaman et al.; Zeybek et al.; Hasegawa et al.; Uhrová et al.; Ismail et al.).

In the present study, single and multiple regression equations were created for the stature estimations of the long bones of the upper and lower extremities of individuals, in our population. In the single regression equations created herein, the standard error of estimate was obtained in the range of 1.94 to $4.09 \mathrm{~cm}$, while it was in the range of 1.68 to $2.24 \mathrm{~cm}$ in the multiple equations.

We believe that the regression equations that were created for stature estimation in the present study will be used effectively and successfully in paleoanthropological studies, as well as forensics and crime scene examinations. In conclusion, stature estimation from limbs or fragmented body parts for the identification and profile of an individual is very important in cases where DNA analysis is limited because of difficulties such as natural events, wars, or mass disasters. We anticipate, in this sense, that the regression equations created in the present study will be an asset in the estimation of stature of individuals in our population, and will aid researchers working in the field of forensics, forensic anthropology, and anatomy.

ACKNOWLEDGMENTS. This study was derived from a doctoral thesis.

AÇıKGÖZ, A. K.; ERKMAN, A. C.; BINOKAY, F.; GÖKER, P. \& BOZKIR, M. G. Estimación de la estatura a partir de mediciones radiográficas en una población adulta de Anatolia. Int. J. Morphol., 39(3):809-815, 2021.

RESUMEN: El propósito del presente estudio fue crear una ecuación de regresión para medir la estatura utilizando medidas obtenidas de las radiografías de huesos largos de individuos adultos en la población de Anatolia. En este estudio, las medidas de longitud máxima de los seis huesos largos en los miembros superiores e inferiores de 167 individuos sanos se determinaron a partir de imágenes radiográficas. Se crearon ecuaciones de regresión única y múltiple para predecir la estatura de los individuos a partir de la estatura ósea máxima. A partir de estas ecuaciones, se determinó el error estándar de estimación en el rango de 1,68 a 4,09 cm. Como resultado de este estudio, las ecuaciones de regresión obtenidas dieron resultados altamente confiables y exitosos en términos de predecir la estatura. Estas ecuaciones proporcionarán una precisión conveniente y predictiva en la estimación de la estatura a partir de restos óseos obtenidos de sociedades que vivieron y viven en Anatolia. Además, anticipamos que guiará a los investigadores que trabajan en los campos de Antropología Forense, Medicina Forense y Anatomía.

PALABRAS CLAVE: Medidas radiográficas; Estimación de la estatura; Ecuación de regresión; Longitud de los huesos largos.

\section{REFERENCES}

Abledu, J. K.; Abledu, G. K.; Offei, E. B. \& Antwi, E. M. Estimation of stature and body weight from footprint dimensions among a female population in Ghana. Aust. J. Forensic Sci., 48(2):195-202, 2016.

Ahmed, A. A. Estimation of stature from the upper limb measurements of Sudanese adults. Forensic Sci Int., 228(1-3):178-e1-178.e7, 2013a.

Ahmed, A. A. Estimation of stature using lower limb measurements in Sudanese Arabs. J. Forensic Leg. Med., 20(5):483-8, 2013 b.

Carretero, J. M.; Rodríguez, L.; García-González, R.; Arsuaga, J. L.; GómezOlivencia, A.; Lorenzo, C.; Bonmatí, A.; Gracia, A.; Martínez, I. \& Quam, R. Stature estimation from complete long bones in the Middle Pleistocene humans from the Sima de los Huesos, Sierra de Atapuerca (Spain). J. Hum. Evol., 62(2):242-55, 2012.

Celbis, O. \& Agritmis, H. Estimation of stature and determination of sex from radial and ulnar bone lengths in a Turkish corpse sample. Forensic Sci Int., 158(2-3):135-9, 2006.

De Mendonça, M. C. Estimation of height from the length of long bones in a Portuguese adult population. Am. J. Phys. Anthropol., 112(1):39-48, 2000.

Duyar, I.; Pelin, C. \& Zagyapan R. A new method of stature estimation for forensic anthropological application. Anthropol. Sci., 114:23-7, 2006.

Giurazza, F.; Del Vescovo, R.; Schena, E.; Battisti, S.; Cazzato, R. L.; Grasso, F. R.; Silvestri, S.; Denaro, V. \& Zobel, B. B. Determination of stature from skeletal and skull measurements by CT scan evaluation. Forensic Sci Int., 222(1-3):398.e1-e9, 2012.

Hasegawa, I.; Uenishi, K.; Fukunaga, T.; Kimura, R. \& Osawa, M. Stature estimation formulae from radiographically determined limb bone stature in a modern Japanese population. Leg. Med. (Tokyo), 11(6):260-6, 2009.

Ismail, N. A.; Khupur, N. H. A.; Osman, K.; Mansar, A. H.; Shafie, M. S. \& Nor, F. M. Stature estimation in Malaysian population from radiographic measurements of upper limbs. Egypt. J. Forensic Sci., 8(1):22, 2018.

Jee, S. C. \& Yun, M. H. Estimation of stature from diversified hand anthropometric dimensions from Korean population. J. Forensic Leg. Med., 35:9-14, 2015.

Karaman, A. G.; Teke, H. Y.; Günay, I.; Dogan, B. \& Bilge, Y. Height estimation using anthropometric measurements on X-rays of wrist and metacarpal bones. Internet J. Biol. Anthropol., 2(1):1-22, 2008. 
Krishan, K. \& Sharma, A. Estimation of stature from dimensions of hands and feet in a North Indian population. J. Forensic Leg. Med., 14(6):32732, 2007.

Lee, J. H.; Kim, Y. S.; Lee, U. Y.; Park, D. K.; Jeong, Y. K.; Lee, N. S.; Han, S. Y. \& Han, S. H. Stature estimation from partial measurements and maximum length of lower limb bones in Koreans. Aust. J. Forensic Sci., 46(3):330-8, 2014.

Nor, F. M.; Abdullah, N.; Mustapa, A. M.; Wen, L. Q.; Faisal, N. A. \& Nazari, D. A. A. A. Estimation of stature by using lower limb dimensions in the Malaysian population. J. Forensic Leg. Med., 20(8):947-52, 2013.

Ozaslan, A.; IIscan, M. Y.; Ozaslan, I.; Tugcu, H. \& Koç, S. Estimation of stature from body parts. Forensic Sci Int., 132(1):40-5, 2003.

Pearson, K. Mathematical contributions to the theory of evolution. V. On the reconstruction of the stature of prehistoric races. Philos. Trans. $R$. Soc. Lond. A, 63:389-400, 1898.

Petrovecki, V.; Mayer, D.; Slaus, M.; Strinovic, D. \& Skavic, J. Prediction of stature based on radiographic measurements of cadaver long bones: a study of the Croatian population. J. Forensic Sci., 52(3):547-52, 2007.

Radoinova, D.; Tenekedjiev, K. \& Yordanov, Y. Stature estimation from long bone lengths in Bulgarians. Homo, 52(3):221-32, 2002.

Sen, J.; Kanchan, T.; Ghosh, A.; Mondal, N. \& Krishan, K. Estimation of stature from lengths of index and ring fingers in a North-eastern Indian population. J. Forensic Leg. Med., 22:10-5, 2014.

Tang, J.; Chen, R. \& Lai, X. Stature estimation from hand dimensions in a Han population of Southern China. J. Forensic Sci., 57(6):1541-4, 2012.

Trotter, M. \& Gleser, G. C. Estimation of stature from long bones of American Whites and Negroes. Am. J. Phys. Anthropol., 10(4):463514, 1952.

Uhrová, P.; Benus, R.; Masnicová, S.; Obertová, Z.; Kramárová, D.; Kyselicová, K.; Dörnhöferová, M.; Bodoriková, S. \& Nescáková, E. Estimation of stature using hand and foot dimensions in Slovak adults. Leg. Med. (Tokyo), 17(2):92-7, 2015.

Zech, W. D.; Näf, M.; Siegmund, F.; Jackowski, C. \& Lösch, S. Body height estimation from post-mortem CT femoral F1 measurements in a contemporary Swiss population. Leg. Med. (Tokyo), 19:61-6, 2016.

Zeybek, G.; Ergur, I. \& Demiroglu, Z. Stature and gender estimation using foot measurements. Forensic Sci. Int., 181(1-3):54.e1-5, 2008

\author{
Corresponding author: \\ Dr. Ahmet Kürsad Açıkgöz, Ph.D. \\ Faculty of Medicine \\ Department of Anatomy \\ Çukurova University \\ 0 1330Adana \\ TURKEY
}

\section{E-mail: akacikgoz@cu.edu.tr ahmetkursadacikgoz@gmail.com}

Received: $13-02-2021$
Accepted: 08-04-2021 